\title{
Realismo nas ruínas da fantasia: História meio ao contrário, de Ana Maria Machado
}

\author{
Claudia Stefanelli \\ Carlos Pires \\ [...] isso explica por que o observador mais perspicaz encontra \\ exatamente nas camadas inferiores da criação literária e artística \\ - como nos livros infantis - aqueles elementos que ele procura em \\ vão nos documentos reconhecidos de cultura. \\ Walter Benjamin (2002, p. 62)
}

Pensar a literatura produzida para crianças no Brasil no contexto particular da ditadura militar pode parecer algo que não apresenta originalidade, ou até um terreno já muito explorado. Como se sabe, muitos autores da época procuraram uma espécie de engajamento bastante particular e questionaram, especialmente a partir da segunda metade dos anos 1970, aspectos consolidados até então na literatura para crianças. Alguns autores e obras, no entanto, se sobressaem pela qualidade e comprometimento com uma proposta literária particular ainda não suficientemente estudada.

Clarice Lispector, um pouco antes, Ana Maria Machado, Ruth Rocha, Lygia Bojunga Nunes, João Carlos Marinho, Henry Correia Araújo, entre outros tantos autores, são exemplos dessa proposta literária para crianças e, alguns, da incorporação de temáticas sociais.

Essa nova forma de fazer literatura, que se propôs a certo desmonte das histórias tradicionais para crianças, começou a acontecer de maneira mais efetiva a partir desse momento histórico e perdura, com significativas transformações, até a literatura produzida hoje, mais de 30 anos depois.

Esse jeito engajado de narrar, pensar personagens, ações e situações menos "encantadas", mas não menos encantadoras, diz respeito, segundo Zilberman (2003, 
p. 195), à "adoção de um programa de perspectiva realista na criação de textos, ao mostrar a vida 'tal qual é' ao leitor mirim".

Para tornar possível essa perspectiva para as crianças, os autores da época adotaram um novo jeito de contar histórias e passaram a fazer uso de recursos estilísticos que viabilizaram conteúdos até então não considerados na literatura infantil, dentre eles, a nova relação entre fantasia e realidade. Segundo Zilberman (2003, p. 176), esses autores passaram "a englobar histórias veristas e fantásticas, miscigenar gente e animais antropomorfizados, simbolizar ou simplificar situações humanas existenciais, misturando até todas essas possibilidades num único texto", o que promove um timbre particular nessa perspectiva realista, que reinventa a relação entre realidade e fantasia.

Esta resenha pretende, portanto, olhar ainda que brevemente para essa nova forma de relacionar fantasia e realidade, surgida nesse contexto histórico específico e ricamente contemplada em História Meio ao Contrárioำ (1977), de Ana Maria Machado.

E então eles se casaram, tiveram uma filha linda como um raio de sol e viveram felizes para sempre...

É dessa maneira que Ana Maria Machado inicia sua História Meio ao Contrário. Logo na abertura apresenta sua intenção de romper com aspectos tradicionais da literatura infantil. Intenção essa que, no decorrer da obra, se concretiza em um efetivo desmonte das histórias tradicionais para crianças, viabilizando, assim, esse "mostrar a vida 'tal qual é' ao leitor mirim".

Após o início meio ao contrário, a narradora, em vez de investir na tradicional linearidade da narrativa, interrompe a história e inicia um diálogo metalinguístico e intertextual com o leitor, no qual tematiza seu processo de escrita e relaciona as formas de contar histórias. Tal estratégia aproxima o leitor de suas intenções e o convida a um papel mais participativo.

\footnotetext{
Tem gente que só quer saber de histórias muito exatas e muito bem arrumadinhas - então é melhor mudar de história, porque essa aqui é meio atrapalhada mesmo e toda ao contrário.
}

Nessa introdução dialógica, a narradora não só deixa explicita a escolha de iniciar pelo fim e a forma que contará a história, como se coloca criticamente diante de alguns problemas contemporâneos à produção do livro (e ainda atuais), como a organização social do homem branco de hoje em dia, por exemplo. Questões sobre maniqueísmo, estilo de vida, papéis sociais das 
personagens e estereótipos culturais são tratados nesse fragmento inicial de forma divertida e desafiadora.

Ao longo da obra, além desses conteúdos, a autora tematiza da mesma forma questões de gênero, relações familiares, sociais e políticas, alienação, autoritarismo, dentre outros temas, o que, segundo Zilberman (2003, p. 191), pode desestabilizar a percepção do leitor, "tanto em relação à literatura como em relação à realidade".

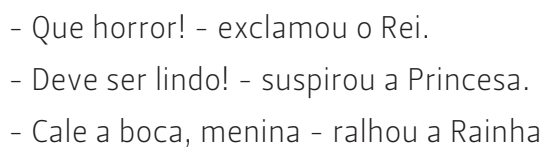

Para tratar desses conteúdos, realidade e fantasia estabelecem em História Meio ao Contrário uma relação reflexiva, na qual a autora ao mesmo tempo em que questiona a fantasia, se utiliza de seus recursos para um arranjo literário verossímil. 0 realismo, então, termo escorregadio, atravessado por uma série de aspectos conflituosos, se estabelece na obra de Ana Maria Machado por meio dos escombros da literatura tradicional para crianças, o que aparece quase como uma necessidade para que ele aconteça de maneira mais efetiva e acessível.

... Viver feliz para sempre não é fácil não. Para falar a verdade, nem é muito
divertido. Fica tudo tão igual a vida inteira que é até sem graça.

Para Zilberman (2003):

\begin{abstract}
Se faltam à criança um senso do real mais desenvolvido, vivências mais profundas e um conhecimento que lhe permita decodificar apropriadamente sua circunstância, não se pode esperar que uma literatura infantil rigorosamente realista preencha o efeito desejado, pois para tanto teria que contar com o que ainda não existe. (p.200).
\end{abstract}

O uso da fantasia, assim, é uma maneira de aproximar o leitor mirim, ou de estabelecer um diálogo mais efetivo com ele, uma vez que constitui a base desse realismo particular que coloca em xeque os valores morais da própria literatura infantil tradicional e da realidade em que a criança leitora está inserida.

Avise a todos que quem conseguir liquidar o monstro terá a mão de minha filha em casamento.

... Eu é que não queria ter que casar com um desconhecido só porque ele é bom de briga... - disse a Pastora. 
Para os padrões da literatura produzida hoje, essa relação realidade e fantasia não apresenta muita novidade. Na época, no entanto, estabeleceu uma nova forma da história se constituir. A maneira como a realidade é representada e construída em atrito com essa ruína da fantasia, ou com essa fantasia que aparece problematizada e problemática de saída, permite que autora abra sua obra para temas que estavam na pauta política daquele momento. Essa estratégia, hoje um tanto desgastada, parecia perspectivar, naquela época e contexto, não apenas a sedução de um provável consumidor, mas buscar um leitor crítico, ou ainda, ter no horizonte a formação de um leitor bastante particular.

\section{REFERÊNCIAS}

BENJAMIN, Walter. Livros infantis velhos e esquecidos, in: Reflexões sobre a criança, o brinquedo e a educação. 34 ed. São Paulo: Duas Cidades, 2002.

MACHADO, Ana Maria. História meio ao contrário. São Paulo: Ática, 2001.

ZILBERMAN, Regina. A literatura infantil na escola. 11 ed. São Paulo: Global, 2003. 